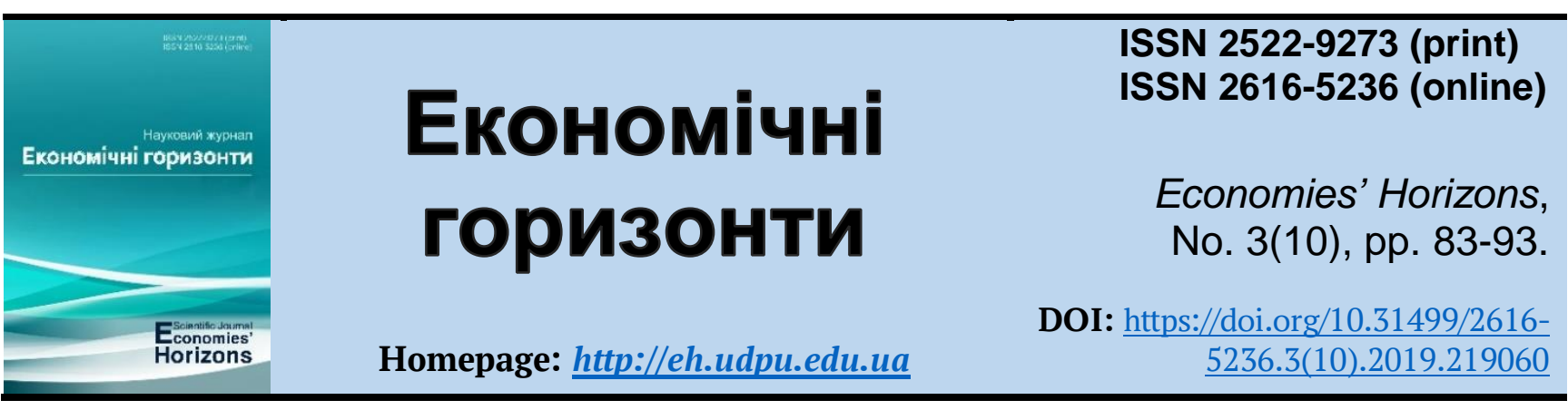

UDC 332.142

\title{
Management models of the region's economic development in the conditions of socialization
}

\author{
Dmytro S. Voit ${ }^{1}$, Cand. Ec. Sc.
}

Received: 2 August 2019

Accepted: 5 September 2019
Voit, D. S. (2019), "Management models of the region's economic development in the conditions of socialization", Economies' Horizons, no.3(10), pp. 83-93, doi: https://doi.org/10.31499/2616-5236.3(10).2019.219060.

Abstract. The purpose of the article is to substantiate the management models of the region's economic development in the conditions of socialization. Methodology. The general scientific methods are used in the research, in particular: theoretical generalization - to determine the main models of development management; statistical analysis - to standardize indicators in each region relative to the national average; methods of positive and normative analysis - to substantiate the management models of the region's economic development in the conditions of socialization. Results. Methodical approaches are considered and the author's definition of the model of management of the region's social and economic development is substantiated. It is proposed to understand it as a unique combination of management functions, mechanisms and tools aimed at identifying key benefits and the most optimal use and development of strategic potential of territories to ensure economic growth, high social standards and environmental protection. Models of social and economic development are substantiated. They determine the level of balance of social and economic processes in the regions using the modified management matrix of R. Blake and J. Mouton and allow us to determine the type of socioeconomic policy in the region, as well as the main ways to balance economic and social efficiency in certain conditions. The matrix contains 5 main sectors that characterize the type of socio-economic policy in the region depending on the results of the social and economic development over a period of time according to certain coordinates. A description of each type of policy is given; the directions of its improvement are substantiated. Practical meaning. Methodical approaches to the assessment of the level of balance of the region's social and economic development are proposed, which are based on the definition of key economic and social results of functioning and their standardization relative to the median value in a $100 \%$ scale. This allows us to determine the rate of advancement (lag) of the regions according to the relevant 2 groups of criteria, to carry out their clustering and to identify problematic areas of socio-economic policy. Prospects for further research. The key principles of formation and functioning of the model are systematized taking into account the current requirements of the time and

\footnotetext{
${ }^{1}$ International University of Business and Law; Doctoral Student; ORCID ID: https://orcid.org/0000-00033406-2237; e-mail:management@nuos.edu.ua.
} 
the main trends of regional governance, which are typical for developed countries, namely: identification and strengthening of the key competencies of the region; compliance with the sustainable development criteria; innovative divergence; stability and balance.

Keywords: management model, regional development, socialization.

JEL Classification: H00, H11, H19, H55, H77.

Number of references: 10; number of tables: 2; number of figures: $\mathbf{0}$; number of formulas: $\mathbf{1 .}$

\title{
Моделі управління економічним розвитком регіону в умовах соціалізації
}

\author{
Дмитро Сергійович Войт ${ }^{1}$, к. е. н.
}

Стаття надійшла: 02.08.2019

Стаття прийнята: 05.09.2019
Voit D. S. Management models of the region's economic development in the conditions of socialization. Економічні горизонти. 2019. № 3(10). C. 83-93. DOI: 10.31499/2616-5236.3(10).2019.219060.

Анотація. Метою статті $\epsilon$ обгрунтування моделей управління економічним розвитком регіону в умовах соціалізації. Методологія. У досліджені застосовані загальнонаукові методи, зокрема: теоретичне узагальнення - для визначення основних моделей управління розвитком; статистичного аналізу - для стандартизації показників у кожному регіоні відносно середнього значення по країні; методи позитивного і нормативного аналізу - для обгрунтування моделі управління економічним розвитком регіону в умовах соціалізаціі. Результати. Розглянуто методичні підходи та обгрунтовано авторське визначення моделі управління соціальноекономічним розвитком регіону, під якою запропоновано розуміти унікальне поєднання управлінських функцій, механізмів та інструментів, що спрямовані на виявлення ключових переваг та найбільш оптимального використання й розвитку стратегічного потенціалу територій для забезпечення зростання економіки, високих соціальних стандартів та збереження навколишнього середовища. Обгрунтовано моделі соціально-економічного розвитку, що визначають рівень збалансованості соціальних і економічних процесів у регіонах з використанням модифікованої управлінської матриці Р. Блейка та Дж. Моутон та дозволяють визначати тип соціальноекономічної політики у регіоні а також основні шляхи збалансування економічної та соціальної ефективності функціонування у визначених умовах. Матриця містить 5 основних секторів, що характеризують тип соціально-економічної політики у регіоні у залежності від результатів соціального та економічного розвитку за певний проміжок часу відповідно до визначених координат: активна, фасадна, реактивна, пасивна та меркантильна. Подано опис кожного типу політики, обгрунтовано напрямки іiі удосконалення. Практичне значення. Запропоновано методичні підходи до оцінки рівня збалансованості соціального й економічного розвитку регіону, що грунтуються на визначенні ключових економічних і соціальних результатів функціонування та їх стандартизації відносно медіанного значення у 100\% шкалі, що дозволяє визначати темпи випередження(відставання) регіонів за відповідними 2 групами критеріїв, здійснювати їх кластеризацію та ідентифікувати проблемні напрямки соціально-економічної політики. Перспективи

${ }^{1}$ Міжнародний університет бізнесу і права; докторант; ідентифікатор ORCID: https://orcid.org/00000003-3406-2237; e-mail: management@nuos.edu.ua. 
подальщих досліджень. Систематизовано ключові принципи формування та функціонування моделі із врахуванням актуальних вимог часу та основних трендів регіонального управління, що є характерними для розвинутих країн, а саме: визначення та посилення ключових компетенцій регіону; відповідність критеріям сталого розвитку; інноваційна дивергентність; стабільність і збалансованість.

Ключові слова: модель управління, розвиток регіону, соціалізація

Кількість джерел: 10; кількість таблищь: 2; кількість рисунків: 0; кількість формул: 1.

\section{Introduction.}

At the present stage, characterized by transformational processes in the management and regions development under the influence of changing external factors, as well as in the reforms implementation, one of the important strategic objectives is to build an optimal model of economic development, which takes into account the opportunities for efficient use of domestic potential and provide sustainable economic growth and human development.

Features and problems of the regional development in Ukraine are related to the processes of socialization, its active institutionalization and the need to provide profound changes in the transition from research to practical implementation, from social potential to social capital in society. The social problems of most regions were formed during the period of market transformation and are associated with inconsistencies in the reforms implementation, their destructive focus and complete lack of control, inconsistency with world standards and so on (Mann, 2014).

\section{Literature review.}

Ukrainian and foreign scientists have paid considerable attention to the study of the peculiarities of the management of the region's economic development. They are R. Mann (2014), V. Tomareva-Patlakhova (2013), I. Kramarenko (2015), A. Prokopyuk (2015), I. Irtyshcheva, T. Stroyko and
I. Krupitsa (2013), S. Zulfugarova (2010) and others. A. However, the constant processes of socialization, its active institutionalization and the need to provide profound changes in the transition from research to practical implementation require additional research to substantiate the management models of economic development of the region.

\section{Methodology.}

The scientific works of scientists in managing the economic development of the region are the theoretical and methodological basis of the study. To achieve the purpose of the study, the following research methods were used: theoretical generalization - to determine the main models of development management; statistical analysis - to standardize indicators in each region relative to the national average; methods of positive and normative analysis - to substantiate the management models of the region's economic development in the conditions of socialization.

\section{Research objectives.}

The purpose of the article is to substantiate the management models of the region's economic development in the conditions of socialization.

\section{Results and discussions.}

Providing sustainable development in the long run is possible only if the implementation of the governance mechanism, which balances the interests of the state, business 
and society, increases opportunities to meet the needs of present and future generations while preserving the environment.

The analysis of the scientific literature showed that there are different approaches to the formation and implementation of the regions' socio-economic development models. Thus, V. Tomareva-Patlakhova classifies the models of regional development depending on the chosen strategy and key resources. The author identifies the following types of models:

1. The ecological and economic model provides for the formation of the relationship between the region's natural subsystem and the region's economy as equal elements of the regional system;

2. The innovation and investment model, in which scientific achievements and their technological application are the main source of the long-term economic growth. The introduction of innovations increases the competitiveness of the region's economy and guarantees its economic security;

3. The innovative one is based primarily on the formation and use of scientific and technical potential. The model provides for the creation of conditions for the knowledgeintensive industries development, training and technologies implementation in all areas of economic activity.

4. The cluster model is aimed at forming the clusters that involve the technological integration of self-sufficient cooperative business structures formed on the basis of labor and specialization division into territorial production systems to organize the production of certain final products, services or work within certain territories.

5. The mobilization and innovation model is aimed at forming the new format scientific and technical potential, which is possible in the case of improving the forms of scientific personnel training and expanding the scope of scientific and technical developments.

6. The model of sustainable development of the regions is aimed at providing a balance between economic, social and environmental development. The model provides for all decisions on the development of territories, taking into account the principles of economic efficiency, social justice and environmental security (Tomareva-Patlakhova, 2013).

The identified models are based primarily on the internal resources of the region and the choice of priority ways to use them. However, only one of the proposed models takes into account the social factor and the search for ways to balance the mechanisms of economic and social development, subject to the implementation of the principles of environmental safety of economic activity. This is a model of sustainable development that is recognized as the most optimal in the EU and other developed countries.

A. Prokopyuk identifies the models of regional development based on a certain state doctrine. The author identifies the doctrines that define the main directions and principles of state regional policy:

- the doctrine of "the regions that are the engines of growth" - to create conditions for increasing competitiveness and concentration of productive resources and capital in certain areas, which can significantly increase the rate of economic growth of these territories and, due to diffusion, business activity spreads to other territories. The advantages of the doctrine are the positive impact of these territories on the formation of the country's 
export potential, the implementation of pilot projects for the introduction of innovative technologies, accelerated development of science and technology, the formation of human capital. An example of "the regions that are the engines of growth" is the creation of megacities, which provide accelerated development (including on the basis of new technologies) compared to peripheral areas. The disadvantages of this approach are significant inter-territorial disparities in economic development, living standards, rising social tensions and conflicts, significant internal migration, which results in structural distortions of demographic potential.

- the doctrine of the regional development equalization, in which the state focuses on equalizing economic and social disparities using mechanisms for redistribution of budgetary resources, the creation of development funds, the use of other instruments to help poor regions. The practice of applying this approach in Ukraine has shown its insufficient effectiveness. Budget transfers, which were used mainly to provide social guarantees, had only a temporary effect on the demand and business activity increasing. The inability to effectively allocate limited budgetary resources between regions, the conflicting vision of development priorities at the local and state levels, the lack of transparency and control failed to provide a sufficient economic growth and a significant increase in living standards. This has been one of the reasons for the introduction of decentralization reform, in which each region and its administrative components are given additional powers and rights to effectively manage local resources;

- the doctrine of "focused" development is similar in content to the doctrine of "the regions that are the engines of growth". In particular, the state consciously assumes significant interregional differentiations by concentrating attention, resources and investments on certain territories. This provides the accelerated growth of certain types of economic activity in which the country specializes in the international labor division. The regions recognized as the official focus of growth receive strong political support, a relaxed fiscal regime, and business and investment incentives. The author notes that "the application of such a model requires costs (investment, administrative) for the implementation of many programs and projects and is associated with certain risks associated with errors of strategic choice, failures of management mechanisms, etc." (Prokopyuk, 2015).

The models of the regions' socioeconomic development proposed by S. Zulfugarova are interesting from the point of view of social aspect (Zulfugarova, 2010). The author considers the region as a system that should strive for an ideal state. The use of the model is proposed to optimize the distribution of budget funds for the development of the region. And the criteria for the effectiveness of such a distribution are combined into blocks that characterize certain areas of the social environment:

1. "BEAUTY": visits to cultural and leisure institutions per year per thousand population; the total circulation of the region's media per thousand population and the number of radio stations and local TV channels; the number of people covered by various sports per thousand population.

2. "GOOD": the number of crimes per thousand population of the region; Ginny index; environmental load indicator.

3. "TRUTH": the number of highly qualified employees (candidates and doctors 
of sciences) engaged in research work per thousand population of the region; the percentage of the population covered by secondary education; the percentage of the population covered by higher education.

4. "WEALTH": GVA per capita; average gross income per capita; percentage of relatively healthy residents of the region.

The study showed that there is no single model that will work equally effectively in the specific conditions of each region. However, in modern conditions, its effectiveness will depend on compliance with the basic principles that have become a trend in developed countries:

1. Identification and strengthening of key competencies, i.e. types of economic activity, industries and resources that can be most effectively used in the region, given the available territorial, natural and climatic, resource, human, scientific and technical, cultural and production potential. Regional development in the EU is based on identifying and stimulating production and services that become drivers of territorial development, form the main cash flows and sources of local budgets, act as factors of interregional exchange and exports and have a multiplier effect on other economic and social sectors.

2. Compliance with the principles of sustainable development, i.e. providing a balance between economic efficiency, social justice and environmental security.

3. Innovative divergence, which involves the introduction of innovative technologies in all spheres of economic, social and management activities in the region, the creation of an innovative ecosystem based on the latest scientific and technical advances.

4. Stability of functioning, i.e. the ability to maintain the positive parameters of the re- gional systems development over the long term.

5. Balance of functioning, which provides for optimal quantitative and qualitative proportions of economic development, social and environmental spheres.

That is, the modern model of social and economic development of the region is a unique combination of management functions, mechanisms and tools aimed at identifying key benefits and the most optimal use and development of strategic potential of territories to provide economic growth, high social standards and environmental protection.

An important issue in modern conditions is the balancing of social and economic development indicators of the regions, taking into account the synergistic effect. That is, providing high economic results in the region should be accompanied by appropriate development of the social sphere. And the development of human capital, as a consequence of effective social policy in the long run has a positive impact on increasing the competitiveness of the regional economy and providing high rates of economic growth. The final indicator of economic development is the gross regional product, which determines the economic activity results of all economic entities of the region. To provide comparability, the paper uses the indicator of GRP per capita, which characterizes the volume of products, works and services in the region, which are on average per capita. Table 1 shows the dynamics of GRP per capita for the period of 2014-2018.

During the period of 2014-2018, the nominal GRP per capita in some regions has more than doubled. The highest growth rates (over 150\%) are in Chernihiv, Vinnytsya, 
Volyn, Zhytomyr, Poltava and Cherkasy regions. Low growth rates are in Luhansk (15.8\%) and Donetsk (65.5\%) regions, which is due to a significant loss of production potential and occupation of part of the territories, as well as in Rivne region. Unfortunate- ly, the significant growth rates of GRP per capita are partly explained by population decline and the rapid development of inflation. The economy of most regions is developing extensively, which negatively affects the living standards of the population.

Table 1. GRP per capita in terms of regions of Ukraine, UAH

\begin{tabular}{|l|c|c|c|c|c|c|}
\hline & $\mathbf{2 0 1 4}$ & $\mathbf{2 0 1 5}$ & $\mathbf{2 0 1 6}$ & $\mathbf{2 0 1 7}$ & $\mathbf{2 0 1 8}$ & $\begin{array}{c}\text { Increase } \\
\mathbf{2 0 1 8} / \\
\mathbf{2 0 1 4}(+/-), \mathbf{\%}\end{array}$ \\
\hline Region & $\mathbf{3 6 9 0 4}$ & $\mathbf{4 6 4 1 3}$ & $\mathbf{5 5 8 9 9}$ & $\mathbf{7 0 2 3 3}$ & $\mathbf{8 4 2 3 5}$ & $\mathbf{+ 1 2 8 . 3}$ \\
\hline Vinnytsya & 27249 & 37270 & 46615 & 58384 & 71104 & +160.9 \\
\hline Volyn & 23218 & 30387 & 34310 & 49987 & 58297 & +151.1 \\
\hline Dnipropetrovsk & 53749 & 65897 & 75396 & 97137 & 114784 & +113.6 \\
\hline Donetsk & 27771 & 26864 & 32318 & 39411 & 45959 & +65.5 \\
\hline Zhytomyr & 23678 & 30698 & 38520 & 49737 & 62911 & +165.7 \\
\hline Zakarpattya & 19170 & 22989 & 25727 & 34202 & 41706 & +117.6 \\
\hline Zaporizhzhya & 37251 & 50609 & 59729 & 75306 & 85784 & +130.3 \\
\hline Ivano-Frankivsk & 27232 & 33170 & 37220 & 46312 & 57033 & +109.4 \\
\hline Kyiv & 46058 & 60109 & 74216 & 90027 & 112521 & +144.3 \\
\hline Kirovohrad & 29223 & 39356 & 47469 & 55183 & 67763 & +131.9 \\
\hline Luhansk & 14079 & 10778 & 14251 & 13883 & 16301 & +15.8 \\
\hline Lviv & 28731 & 37338 & 45319 & 58221 & 70173 & +144.2 \\
\hline Mykolayiv & 30357 & 41501 & 50091 & 60549 & 70336 & +131.7 \\
\hline Odesa & 31268 & 41682 & 50159 & 62701 & 72738 & +132.6 \\
\hline Poltava & 48040 & 66390 & 81145 & 106248 & 123763 & +157.6 \\
\hline Rivne & 24762 & 30350 & 33958 & 42038 & 49044 & +98.1 \\
\hline Sumy & 26943 & 37170 & 41741 & 51419 & 62955 & +133.7 \\
\hline Ternopil & 20228 & 24963 & 29247 & 38593 & 46833 & +131.5 \\
\hline Kharkiv & 35328 & 45816 & 57150 & 69489 & 86904 & +146.0 \\
\hline Kherson & 21725 & 30246 & 36585 & 45532 & 52922 & +143.6 \\
\hline Khmelnytskyi & 24662 & 31660 & 37881 & 49916 & 59583 & +141.6 \\
\hline Cherkasy & 30628 & 40759 & 48025 & 59697 & 76904 & +151.1 \\
\hline Chernivtsi & 16552 & 20338 & 23365 & 31509 & 37441 & +126.2 \\
\hline Chernihiv & 26530 & 35196 & 41726 & 55198 & 69725 & +162.8 \\
\hline The City of Kyiv & 124163 & 155904 & 191736 & 238622 & 283097 & +128.0 \\
\hline
\end{tabular}

Source: data of the State Statistics Service of Ukraine (2019).

The average annual income per capita in Ukraine in 2018 was UAH 58,442, which is $118 \%$ more than in 2014. The highest level of income is observed in the City of Kyiv and over 144 thousand UAH, the lowest - in Luhansk region -21.2 thousand UAH. The 
growth rate of average per capita income in almost all regions during the study period is above $100 \%$. It is primarily due to a significant increase in the minimum wage, the indexation of certain social benefits, as well as an increase in remittances from abroad.

To determine the level of balance of social and economic development, a rating assessment of the regions by the level of GRP and disposable income per capita was carried out. The assessment methodology is based on the standardization of indicators in each region relative to the national average by the formula:

$$
S_{p r}^{t}=\frac{P_{r}^{t}}{\bar{P}^{t}} \times 100,
$$

where $S_{p r}^{t}$ is the standardized value of the indicator of economic (social) development of the region in the period $t$;

$P_{r}^{t}$ is the actual value of the indicator of economic (social) development of the region in the period $t$;

$\bar{P}^{t}$ is the average value of the indicator of economic (social) development achieved by a sample of regions in the period $t$;

Using the data in Table 1 and Formula 1 , the standardized (relative to the median value) GRP per capita in the regions was calculated. The results of the calculations are shown in Table 2.

Table data show the significant asymmetries of the regional distribution of GRP relative to the median value. In particular, in 2018 in the five regions (Dnipropetrovsk, Zaporizhya, Kyiv, Poltava, Kharkiv) the level of GRP per capita exceeded the average value by $4-37 \%$, and in the City of Kyiv - more than three times. In 2018, the level of GRP per capita was below $60 \%$ of the average value in Chernivtsi (45\%), Luhansk (19\%), Donetsk (55\%), Ternopil (56\%), Rivne (59\%) and Zakarpattya (50\%) regions. Compared to 2015, the level of disproportions of the studied indicator relative to the average value increased in almost all regions, except Zhytomyr one.

In contrast to GRP, the level of disposable income per capita in most regions of Ukraine is higher than or equal to the median value. If we do not take into account Donetsk and Luhansk regions, which economies are currently in a state of turbulence due to prolonged hostilities and occupation of part of the territories, disparities in this indicator average $20-30 \%$.

Comparing the main final indicators of economic and social development of the Ukrainian regions, namely the gross regional product per capita, it should be noted that these indicators are insufficiently balanced. To illustrate the level of balance of social and economic development of the Ukrainian regions and to choose the model of regional development taking into account the effect of socialization, we proposed to use a modified management matrix of R. Blake and J. Mouton (Blake and Mouton, 1964).

An important aspect of implementing the socialization of the economy is the involvement of all participants in the process "To overcome the obstacles that arise in the way of education and social inclusion, the representatives of government agencies and NGOs should mobilize public opinion, to ensure consensus, to analyze the situation, to support appropriate education and informational projects at their places" (Kramarenko, 2017). 
Table 2. Standardized indicators of GRP and disposable income per capita by regions of Ukraine in 2015 and 2018 , \% relative to the median value

\begin{tabular}{|c|c|c|c|c|c|c|}
\hline \multirow{2}{*}{ Regions } & \multicolumn{2}{|c|}{ GRP per capita } & \multirow{2}{*}{ 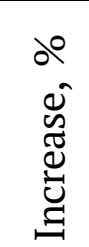 } & \multicolumn{2}{|c|}{$\begin{array}{c}\text { Disposable income } \\
\text { per capita }\end{array}$} & \multirow{2}{*}{ 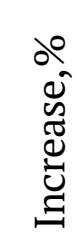 } \\
\hline & 2014 & 2018 & & 2015 & 2018 & \\
\hline Vinnytsya & 89 & 85 & -4 & 98 & 100 & +2 \\
\hline Volyn & 73 & 70 & -3 & 83 & 83 & - \\
\hline Dnipropetrovsk & 157 & 137 & -20 & 129 & 135 & +6 \\
\hline Donetsk & 64 & 55 & -9 & 71 & 61 & -10 \\
\hline Zhytomyr & 73 & 75 & +2 & 92 & 95 & +3 \\
\hline Zakarpattya & 55 & 50 & -5 & 74 & 75 & +1 \\
\hline Zaporizhzhya & 121 & 102 & -19 & 120 & 117 & -3 \\
\hline Ivano-Frankivsk & 79 & 68 & -11 & 88 & 88 & - \\
\hline Kyiv & 143 & 134 & -9 & 112 & 118 & +6 \\
\hline Kirovohrad & 94 & 81 & -13 & 90 & 91 & +1 \\
\hline Luhansk & 26 & 19 & -7 & 52 & 38 & -14 \\
\hline Lviv & 89 & 84 & -5 & 98 & 102 & +4 \\
\hline Mykolayiv & 99 & 84 & -15 & 97 & 100 & +3 \\
\hline Odesa & 99 & 87 & -12 & 107 & 114 & +7 \\
\hline Poltava & 158 & 148 & -10 & 106 & 111 & +5 \\
\hline Rivne & 72 & 59 & -13 & 88 & 87 & -1 \\
\hline Sumy & 89 & 75 & -14 & 101 & 101 & - \\
\hline Ternopil & 60 & 56 & -4 & 79 & 78 & -1 \\
\hline Kharkiv & 109 & 104 & -5 & 106 & 102 & -4 \\
\hline Kherson & 72 & 63 & -9 & 92 & 90 & -2 \\
\hline Khmelnytskyi & 76 & 71 & -5 & 97 & 91 & -6 \\
\hline Cherkasy & 97 & 92 & -5 & 89 & 91 & +2 \\
\hline Chernivtsi & 49 & 45 & -4 & 79 & 77 & -2 \\
\hline Chernihiv & 84 & 83 & -1 & 94 & 92 & -2 \\
\hline The City of Kyiv & 372 & 338 & -34 & 253 & 259 & +6 \\
\hline
\end{tabular}

Source: calculated by the author on the basis of the data of the State Statistics Service of Ukraine (2019).

Solving of this problem situation should become the main goal of institutional providing of Ukrainian social-economic system development. The institutional environment of modern Ukraine won't be able to solve the existing problem because it includes institutions of low quality, effective self organiza- tion of which is naturally impossible. Thus, the concept of institutional changes is an effective instrument of economic policy, with the help of which it is possible to eliminate the problems of institutional providing of the country development (Irtyshcheva and Gurina, 2018). 


\section{Conclusions.}

Methodical approaches are considered and the author's definition of the model of management of the region's social and economic development is substantiated. It is proposed to understand it as a unique combination of management functions, mechanisms and tools aimed at identifying key benefits and the most optimal use and development of strategic potential of territories to provide economic growth, high social standards and environmental protection. The key principles of formation and functioning of the model are systematized taking into account the current requirements of the time and the main trends of regional governance, which are typical for developed countries, namely: identification and strengthening of the key competencies of the region; compliance with the sustainable development criteria; innovative divergence; stability and balance.

Methodical approaches to the assessment of the level of balance of the region's social and economic development are proposed, which are based on the definition of key economic and social results of functioning and their standardization relative to the median value in a $100 \%$ scale. This allows us to determine the rate of advancement (lag) of the regions according to the relevant 2 groups of criteria, to carry out their clustering and to identify problematic areas of socio-economic policy.

Models of social and economic development are substantiated. They determine the level of balance of social and economic processes in the regions using the modified management matrix of R. Blake and J. Mouton and allow us to determine the type of socioeconomic policy in the region, as well as the main ways to balance economic and social efficiency in certain conditions. The matrix contains 5 main sectors that characterize the type of socio-economic policy in the region depending on the results of the social and economic development over a period of time according to certain coordinates. A description of each type of policy is given; the directions of its improvement are substantiated.

\section{References}

Blake, R. and Mouton, J. (1964), The managerial grid: The key to leadership excellence, Gulf Publishing Co, Houston, USA.

Irtyshcheva, I. O. and Gurina, O. V. (2018), "Methodical approaches to the assessment of the processes of economic development of regions in the conditions of socialization", Socio-economic problems of the modern period of Ukraine, no. 3, pp. 92-98.

Irtyshcheva, I. O., Stroyko, T. V. and Krupitsa, I. V. (2013), "Formation of institutional changes management system under the conditions of socialization of national economy", The Bulletin of the Kharkiv National Agricultural University named after V. V. Dokuchaev. Series "Economic Sciences", no. 6, pp. 3-9.

Kramarenko, I. (2015), "Development of educational and social inclusion in conditions of social transformation of Ukraine”, TILTAI, vol. 72, no. 3, pp. 83-90. doi: http://dx.doi.org/10.15181/tbb.v72i3.1167

Kramarenko, I. (2017), "Social-economic and intellectual development of Ukraine: Regional and national aspect”, Danish scientific journal, no. 1, pp. 20-28.

Mann, R. V. (2014), "The key direction of regional management - the processes of socialization, Manager. Bulletin of Donetsk State University of Management, no. 1 (67), pp. 142-148.

Prokopyuk, A. (2015), "Principles of forming a new model of regional development on the basis of structural transformations", Socio-economic problems of the modern period of Ukraine, no. 5(115), pp. 93-97. 
The State Statistics Service of Ukraine (2019), “Statistical information”, available at: http://www.ukrstat.gov.ua (Accessed 23 July 2019).

Tomareva-Patlakhova, V. V. (2013), "Models of regional development in the context of economic reforms”, State and regions. Series: Economics and Entrepreneurship, no. 1 (70), pp. 76-80.

Zulfugarova, S. O. (2010), “The models of regional economic development”, Ph.D. Thesis, Mathematical methods, models and informative technologies in economics, Classical Private University, Zaporizhzhia, Ukraine. 